\title{
Genetic alterations in head and neck squamous cell carcinomas
}

M.A. Nagai

\author{
Correspondence \\ M.A. Nagai \\ Disciplina de Oncologia \\ Departamento de Radiologia \\ Faculdade de Medicina, USP \\ Av. Dr. Arnaldo, 455, 40 andar \\ 01296-903 São Paulo, SP \\ Brasil \\ E-mail: nagai@ usp.br \\ nagai@ mandic.com.br \\ Presented at the I International \\ Symposium on "Signal Transduction \\ and Gene Expression in Cell \\ Proliferation and Differentiation", \\ São Paulo, SP, Brasil, \\ August 31-September 2, 1998.
}

Publication supported by FAPESP.

Received November 26, 1998 Accepted M arch 2, 1999
Disciplina de O ncologia, Departamento de Radiologia, Faculdade de Medicina, U niversidade de São Paulo, São Paulo, SP, Brasil

\section{Abstract}

The genetic alterations observed in head and neck cancer are mainly due to oncogene activation (gain of function mutations) and tumor suppressor gene inactivation (loss of function mutations), leading to deregulation of cell proliferation and death. These genetic alterations include gene amplification and overexpression of oncogenes such as $m y c$, erbB-2, EGFR and cyclinD1 and mutations, deletions and hypermethylation leading to p16 and TP53 tumor suppressor gene inactivation. In addition, loss of heterozygosity in several chromosomal regions is frequently observed, suggesting that other tumor suppressor genes not yet identified could be involved in the tumorigenic process of head and neck cancers. The exact temporal sequence of the genetic alterations during head and neck squamous cell carcinoma (HNSCC) development and progression has not yet been defined and their diagnostic or prognostic significance is controversial. Advances in the understanding of the molecular basis of head and neck cancer should help in the identification of new markers that could be used for the diagnosis, prognosis and treatment of the disease.

\section{Key words}

- Genetic alterations

- Oncogene

- Tumor suppressor gene

- Head and neck cancer

\section{Introduction}

Squamous cell carcinoma of the head and neck is an epithelial malignant disease arising from the mucosa of the upper aerodigestive tract (oral cavity, larynx, oropharynx and hypopharynx). The disease is characterized by local tumor aggressiveness, early recurrence and high frequency of second primary tumors. Synchronous or metachronous multiple lesions occurring in the same patient have led to the field cancerization hypothesis (1). According to which prolonged exposure of the epithelium to certain carcinogenic agents (tobacco and alcohol) could induce cellular alterations and tumor forma- tion at multiple anatomical sites. Second primary tumors arise mainly in regions exposed to tobacco, including esophagus, lung and other areas of the upper aerodigestive tract (1). In fact, epidemiological data implicate tobacco smoking and alcohol consumption as the major risk factor for the disease (2).

The relative risk of developing cancer in individuals exposed to tobacco varies from person to person, depending in part on genetic components related to cancer susceptibility. There have been few data showing evidence of inheritance in head and neck squamous cell carcinoma (HNSCC) (3); however, common genes with low penetrance related to cancer susceptibility might account 
for some of these tumors. The status of genes encoding drug-detoxifying enzymes (expression or form variation) determines how cells activate and detoxify chemical carcinogens. The active metabolites of chemical carcinogens covalently bind to the DNA and form adducts, which lead to mutations. Several studies have demonstrated variable levels of DNA adduct formation depending on the genotype of certain enzymes, such as CYP1A1 (cytochrome p4501A1), NATs (Nacetyltransferases) and GSTM1 (glutathioneS-transferase) and the risk to develop several types of tumors (4). An association between the genotype pattern of the enzymes CYP $1 A 1$ (5), NAT2 (6), GSTM1 and GSTM3 (7) and increased susceptibility to the development of HNSCC has been recently shown. These results indicate that these genetic polymorphisms could predict the levels of DNA adducts formed by certain carcinogens and could, therefore, predict the individual response to the exposure of these compounds and could be used to assess the risk and to

Table 1 - Summary of the genetic alterations observed in head and neck squamous cell carcinomas.

Oncogene activation

ras

Mutation and overexpression

11q13 (int-2/bcl-1/PRAD-1) Amplification

Cyclin D1 (PRAD-1) Amplification and overexpression

myc, EGFR, TGFß Overexpression

Loss of heterozygosity ( $>25 \%$ )

$1 p, 1 q$

$3 p, 4 q$

$5 p, 5 q$

$6 p, 6 q$

$8 p, 9 p$

$11 q, 13 q$

$14 q, 17 p$

$18 \mathrm{q}$

Tumor suppressor gene inactivation

TP53

Mutations and deletions

p16 prevent the disease.

Human papilloma virus (HPV) infection has also been implicated in the etiology of HNSCC tumors. There is a prevalence of HPVs type 16 and 18 among HPV-positive head and neck patients. HPV infection has been found in 18 to $35 \%$ of benign and preinvasive lesions; in invasive carcinomas, HPV positivity is higher in tumors from the oral cavity (59\%), pharynx (43\%) and larynx $(33 \%)(8)$. In spite of the evident role played by HPV infection in HNSCC etiology its clinical implications or prognostic and diagnostic value have not yet been established.

\section{Genetic alterations}

\section{Oncogene activation}

Several cytogenetic and molecular studies have investigated the occurrence of genetic alterations in HNSCC, demonstrating that oncogene activation and tumor suppressor gene inactivation are involved in the development of the disease (Table 1). Genetic alterations, mainly gene amplification, mutation and overexpression, leading to oncogene activation have been observed in HNSCC; however, these studies are preliminary and involve a small number of patients and short follow-up. Data about the relationship of these genetic changes with disease progression and patient outcome have been inconclusive.

ras mutations have been identified in less than $5 \%$ of the head and neck tumors from Western world patients (9). A high incidence $(35 \%)$ of Ha-ras mutations has been reported in oral squamous cell carcinomas from India (10). In this case betel quid chewing and reverse smoking are probably initiating agents (11). Whereas activating ras mutations appear to be an infrequent event in head and neck tumors from the Western world, studies using immunohistological staining and RT-PCR have demonstrated that overexpression c-Ha-ras is a common event 
in these tumors $(11,12)$. However, the exact mechanism accounting for ras overexpression is unknown and its association with existing prognostic factors is not yet clear.

Amplification and overexpression of the oncogenes $m y c, e r b B-2$ and epidermal growth factor receptor $(E G F R)$ have been observed in HNSCC, and are correlated with a poor prognosis. The members of the myc gene family (c-myc, N-myc, L-myc) encode for a $62-\mathrm{kDa}$ protein with transactivational activity (13). The myc proteins (p62 ${ }^{\mathrm{myc}}$ ) are able to dimerize with a second protein, $\max$. Overexpression of myc leads to increased amounts of myc-max heterodimers and reduced maxmad heterodimer formation (13), changing the regulation of many genes and contributing to malignant transformation. The frequency of c-myc amplification and overexpression reported in the literature varies from 9 to $48 \%(14,15)$. Using immunohistochemistry, Field et al. (14) observed c-myc amplification in $48 \%$ of the tumors analyzed. Although no association has been found between the c-myc amplification and sex, gender, tumor size, clinical stage or differentiation, these investigators observed that patients with tumors with high levels of c-myc showed shortened overall survival. In addition, Porter et al. (16) demonstrated c-myc amplification in $22 \%$ of tumors from the nasopharynx and observed that the prognosis for patients with tumors with c-myc amplification was worse compared with patients with tumors without c-myc amplification.

c-erbB-2 gene (also named neu or Her-2) encodes for a $185-\mathrm{kDa}$ protein with tyrosine kinase activity, homologous to the $E G F R$ (17). c-erbB-2 amplification and overexpression have been observed in several human tumors $(18,19)$. In head and neck carcinomas, the frequencies of $e r b B-2$ amplification and overexpression range from 0 to $41 \%$ (20-22). The prognostic value of these genetic alterations observed in $e r b B-2$ oncogene is controversial. Field et al. (14) and
Craven et al. (21) reported a lack of correlation between erbB-2 overexpression and clinicopathological characteristics or patient survival. However, Press et al. (22) observed that patients with salivary gland tumors with erbB-2 overexpression have a poor prognosis.

The EGFR gene is frequently amplified and overexpressed in cell lines and primary head and neck tumors. A good correlation has been found between the presence of $E G F R$ genetic alterations and poor prognosis, particularly in head and neck tumors of the larynx. Amplification and overexpression of EGFR have been detected in $61 \%$ of larynx tumors and the elevated expression was associated with a poor prognosis (23). In addition, $E G F R$ overexpression has been found primarily in poorly differentiated larynx tumors and in tumors from patients with short disease-free interval and overall survival $(24,25)$.

Amplification of the 11q13 region is frequently observed in head and neck tumors. Several putative oncogenes have been identified on 11q13, including bcl-1, int-2, hst-1, EMS-1 and cyclin D1/PRAD-1. Amplification and coamplification of $b c l-1$, int-2 and hst-1 have been found in $30-52 \%$ of the head and neck tumors $(26,27)$. The int-2 (FGF3) and hst-1 (FGF4) oncogenes are members of the fibroblast growth factor $(F G F)$ associated with the induction of cell proliferation and angiogenesis. These genes are considered good candidates to play an important role in the genesis of HNSCC $(11,28)$. A high frequency of hst-1/FGF4 and bcl-1 amplification has been observed in tumors of the hypopharynx and in lymph node-positive patients (27). However, amplification of these genes is not followed by overexpression, suggesting that other genes located in the $11 \mathrm{q} 13$ region could be involved in the tumorigenic process of the head and neck.

Cyclin D1/PRAD-1 and EMS-1 genes are also considered to be possible targets of $11 \mathrm{q} 13$ amplification. The $E M S-1$ gene shows 
homology with the v-src substrate and may play a role in cytoskeleton organization and cell adhesion (29). EMS-1 amplification and overexpression were observed in a high proportion of cell lineages derived from head and neck carcinomas (30).

Amplification and overexpression of cyclin D1 have been consistently associated with the tumorigenic process of the head and neck (31). Cyclin D1 is encoded by the $C C N D 1 / P R A D-1$ gene (32) and is among the major regulators of the $\mathrm{G} 1$ restriction point of the cell cycle (33). Cyclin D1 is able to form a complex with cyclin-dependent kinases (CDK4 and CDK6), which phosphorylate $R B$ releasing E2F. Cyclin D1 overexpression has been described in $39-64 \%$ of primary HNSCC $(34,35)$. In a recent study of HNSCC, overexpression of cyclin D1 has been correlated with lymph node metastases and advanced clinical stage (36). In addition, cyclin D1 immunoreactivity is more frequent in tumors of patients with shortened disease-free interval and overall survival $(34,35)$.

\section{Tumor suppressor gene inactivation}

Deletion of specific chromosomal regions is one of the most common genetic events observed in solid tumors and the deleted regions are believed to contain potential tumor suppressor genes. High frequencies of loss of heterozygosity ( $\mathrm{LOH}$ ) involving chromosomal regions 3p, 5q, 8p, 9p, 9q, 11p and $17 \mathrm{p}$ have been reported in HNSCC (37). The highest $\mathrm{LOH}$ frequencies occur on chromosomal arms 3p, 9p and 17p (37,38), which harbor unknown and already cloned tumor suppressor genes, such as VHL (3p), p16 (9p) and TP53 (17p). The occurrence of $\mathrm{LOH}$ in these regions has been associated with the development and progression of the disease $(39,40)$.

Genetic alterations involving the tumor suppressor genes p16 and TP53 are frequently observed in head and neck tumors. Inactiva- tion of both of these genes appears to be involved in the early stages of the disease. However, the diagnostic and prognostic value of these genes remains unclear at present.

The p16 tumor suppressor gene located on chromosome 9p21 encodes a 16-kDa protein that belongs to an important group of cyclin-dependent kinase inhibitors (CDKIs) which includes $\mathrm{p} 15^{\text {ink } 4 \mathrm{~b}}, \mathrm{p} 21^{\text {wafl }}$ and $\mathrm{p} 27^{\mathrm{kip} 1}$. These genes regulate the G1 phase of the cell cycle in a negative way. The 16 gene product binds to CDK4 and CDK6 inhibiting their association with cyclin D1. The inhibition of the cyclin D1/CDK4/6 complex activity prevents $\mathrm{pRB}$ phosphorylation and the release of E2F, leading to inhibition of the cell cycle in the G1-S transition (41). Genetic abnormalities inactivating the p16 gene might confer cell growth advantages contributing to the tumorigenic process.

High frequencies of loss of heterozygosity on the short arm of chromosome 9 (9p21$22)$, where the tumor suppressor gene $\mathrm{p} 16$ is located, have been reported in head and neck tumors, including dysplasia and carcinoma in situ $(39,42)$, suggesting the involvement of this region in the early stages of the disease.

Genetic alterations leading to $\mathrm{p} 16$ inactivation have been detected in 7 to $67 \%$ of head and neck tumors. Point mutations, small deletions and insertions were found in a small subgroup of HNSCC $(43,44)$. Homozygous deletions and hypermethylation have been found in $20-67 \%$ of the HNSCC and are considered to be the major genetic mechanisms for p16 inactivation $(43,44)$. Hypermethylation of the 5' $\mathrm{CpG}$ island of p16 has been associated with gene silencing $(43,45)$. Absent or reduced expression of p16 has been observed in a significant proportion of carcinomas (44) and pre-invasive lesions (46). The high incidence of p16 inactivation in head and neck tumors indicates that this gene plays an important role in the development of the disease. At present, however, the diagnostic or prognostic value of these find- 


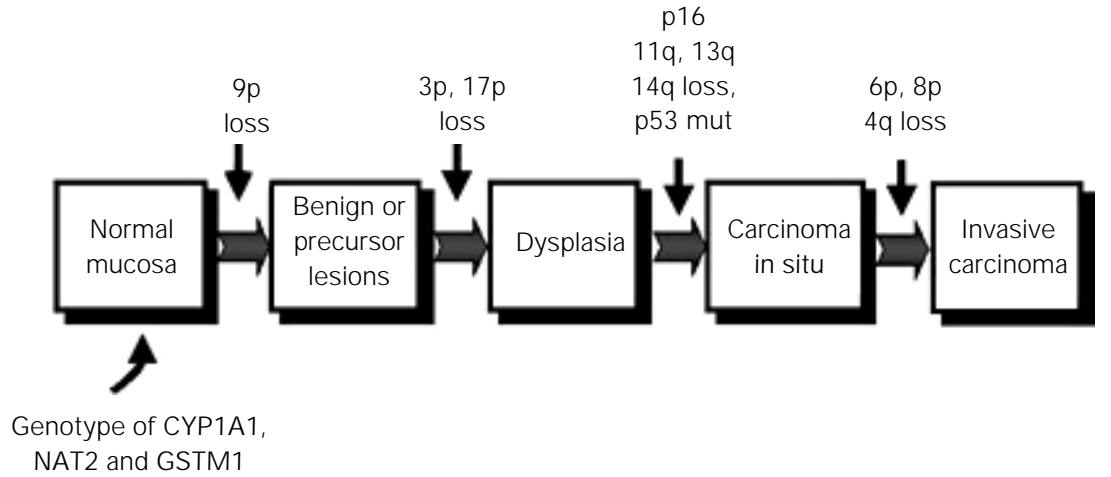

ings remains to be determined.

Genetic alterations leading to loss of normal function of the TP53 tumor suppressor gene is believed to contribute to the development of the majority of human cancers $(47,48)$. The TP53 gene is located on chromosome $17 \mathrm{p} 13.1$ and consists of 11 exons coding for a nuclear phosphoprotein which can bind to specific DNA sequences acting as a transcription factor (49). Most TP53 gene mutations are missense mutations that tend to cluster within exons 5 to 8 , spanning the evolutionarily conserved region of the protein (48). This highly conserved region encompasses amino acids 102 to 292 containing the DNA-binding domain of the protein (50). Many of these point mutations may alter the p53 wild-type conformation, resulting in protein stabilization and accumulation in cells $(51,52)$, which allow their detection by immunohistochemistry. p53 biological activities are complex and have not been completely elucidated. However, a number of findings indicate that $\mathrm{p} 53$ plays an important role in cell-cycle control (both G1/S and $\mathrm{G} 2 / \mathrm{M}$ checkpoints) and in the induction of apoptosis in several different physiological conditions (49).

The TP53 gene is probably the most widely studied gene in head and neck cancer. Immunohistochemical studies have shown accumulation of p53 in 50 to $100 \%$ of cell lines derived from head and neck tumors $(53,54)$. In primary tumors, p53 immunoreactivity was observed in 11 to $79 \%$ of cases (see Ref. 55, for a recent review). Molecular studies show that approximately $50 \%$ of head and neck tumors harbor TP53 mutations (5658). These mutations were distributed among exons 4 to 8 spanning the evolutionarily conserved region of the protein (58).

The exact role of the TP53 genetic alterations in different stages of the tumorigenic process is not completely established. In head and neck tumors p53 immunoreactivity has been observed in normal mucosa of patients with head and neck carcinoma (59) and mutations have been observed in noninvasive lesions (57), suggesting that TP53 inactivation is involved in the early stages of the disease.

TP53 mutations are a common alteration in tobacco-associated cancers $(47,48)$. In head and neck cancer, positive p53 immunostaining is more frequently observed in tumors from patients with a smoking history $(11,60)$. In addition, p53 overexpression is more prevalent in normal mucosa from smoking patients than in normal mucosa from non-smoking patients (54) and $\mathrm{G}: \mathrm{C} \rightarrow \mathrm{T}: \mathrm{A}$ transversions, which are thought to be induced by benzo-pyrene found in tobacco smoke, are more frequently observed in head and neck tumors from patients with a history of tobacco consumption $(47,59)$.

The exact sequence of the genetic events in head and neck cancer has not yet been established. However, based on the detection of loss of heterozygosity in 87 head and neck tumors including benign and pre-invasive lesions, Califano et al. (39) proposed a preliminary progression model for HNSCC
Figure 1 - Molecular model proposed for tumorigenesis in head and neck squamous cell carcinomas (Califano et al. (39), with modifications). The status of genes encoding enzymes (such as CYP1A1, NAT2 and GSTM 1) associated with the metabolism and detoxification of chemical carcinogens might increase the relative risk to develop head and neck cancer. Genetic alterations involving several chromosomal regions are required for normal cells to progress from benign or precursor lesions to dysplasia, to carcinoma in situ and to invasive carcinoma. 
(Figure 1; proposed model with modifications). According to this model, loss of heterozygosity in chromosomal region $9 p$ is already observed in benign and precursor lesions; deletions in chromosomal regions $3 p$ and $17 p$ are observed in dysplasia; deletions in the $11 \mathrm{q}, 13 \mathrm{q}$ and $14 \mathrm{q}$ regions are associated with carcinoma in situ, and deletions involving chromosomal regions $6 \mathrm{p}, 8 \mathrm{p}$ and $4 \mathrm{q}$ are associated with invasive lesions. These investigators point out that it is the accumulation and not necessarily the order of the genetic events that determines tumor progression.

The study of the genetic alterations associated with the carcinogenic process of the head and neck including continued analysis of new genetic alterations and their temporal sequencing during initiation, promotion and progression will allow us to identify new diagnostic and prognostic factors and provide a promising basis for the application of more rational and efficient treatments.

\section{References}

1. Slaughter DP, Southwick HW \& Smejkal W (1953). "Field cancerization" in oral stratified squamous epithelium. Cancer, 6: 963-968.

2. Spitz MR (1994). Epidemiology and risk factors for head and neck cancer. Seminars in Oncology, 21: 281-288.

3. Ankathil R, Mathew A, J oseph F\& Nair MK (1996). Is oral cancer susceptibility inherited? Report of five oral cancer families. Oral Oncology, European J ournal of Cancer, 32B: 63-67.

4. Warren AJ \& Shields PG (1997). Molecular epidemiology: carcinogen-DNA adducts and genetic susceptibility. Molecular Epidemiology, 216: 172-180.

5. Park J Y, Muscat J E, Ren Q, Schantz SP, Hardwick RD, Stern J C, Pike V, Richie J $r$ J P \& Lazarus P (1997). CYP1A1 and GSTM 1 polymorphisms and oral cancer risk. Cancer Epidemiology, Biomarkers and Prevention, 6: 791-797.

6. Gonzalez MV, Alvarez V, Pello MF, Menedez MJ , Suarez C \& Coto E (1998). Genetic polymorphism of N-acetyltransferase-2, glutathione S-transferase-M 1, and cytochrome p450IIE1 and p450IID6 in the susceptibility to head and neck cancer. J ournal of Clinical Pathology, 51: 294298.

7. Mattias C, Bockmuhl U, J ahnke V, Petersen I, Dietel M \& Strange RC (1998). Effect of gene polymorphism on detoxifying glutathione-S-transferase enzymes on chromosomal stability of squamous epithelial carcinomas in the area of the head and neck. Laryngo-rhino-otologie, 77: 201206.

8. McKaig RG, Baric RS \& Olshan AF (1998).
Human papillomavirus and head and neck cancer: epidemiology and molecular biology. Head and Neck, 20: 250-265.

9. Yarbrough WG, Shores $C \&$ Witsel DL (1994). ras mutations and expression in head and neck squamous cell carcinomas. Laryngoscope, 104: 1337-1347.

10. Saranth D, Chang SE \& Bhoite LT (1991). High frequency mutations in codons 12 and 61 of Ha-ras oncogene in chewing tobacco-related human oral carcinoma in India. British J ournal of Cancer, 63: 573578.

11. Field J K (1992). Oncogene and tumour suppressor genes in squamous cell carcinoma of the head and neck. European J ournal of Cancer, 28B: 67-76.

12. Kiaris $H$, Spandidos DA, J ones AS, Vaughan ED \& Field J K (1995). Mutations, expression and genomic instability of the $\mathrm{H}$-ras proto-oncogene in squamous cell carcinomas of the head and neck. British J ournal of Cancer, 72: 123-128.

13. Bouchard C, Staller P \& Eilers M (1998). Control of cell proliferation by myc. Trends in Cell Biology, 8: 202-206.

14. Field JK, Spandidos DA, Stell PM, Vaughan ED, Evan GI \& Moore J P (1989). Elevated expression of the c-myc oncoprotein correlates with poor prognosis in head and neck squamous cell carcinoma. Oncogene, 4: 1463-1468.

15. Rodrigo J P, Lazo PS, Ramos S, Alvarez I \& Suarez C (1996). myc amplification in squamous cell carcinomas of the head and neck. Archives of Otolaryngology Head and Neck Surgery, 122: 504-507.

16. Porter MJ, Field J K, Leung SF, Lo D, Lee JCK, Spandidos DA \& Van Hasselt CA
(1994). The detection of the c-myc and ras oncogenes in nasopharyngeal carcinoma by immunohistochemistry. Acta OtoLaryngologica, 114: 105-109.

17. Schecter $A L$, Stern DF, Vaidyanathan $L$, Decker SJ, Drebin JA, Greene MI \& Weinberg RA (1984). The neu oncogene: an erbB-related gene encoding a 185000 Mr tumor antigen. Nature, 312: 513-516.

18. Gutman M, Ravia Y, Assaf D, Yamamoto T, Rozin R \& Shiloh Y (1989). Amplification of c-myc and c-erbB-2 proto-oncogenes in human solid tumors: frequency and clinical significance. International J ournal of Cancer, 44: 802-805.

19. Slamon DJ, Clark GM, Wong SG, Levin WJ , Ulrich A \& McGuire WL (1987). Human breast cancer: correlation of relapse and survival with amplification of Her-2/ neu oncogene. Science, 235: 177-182.

20. Beckhardt RN, Kiyokawa N, Xi L, Liu T, Hung $M$, El-Naggar AK, Zhang $\mathrm{H}$ \& Clayman GL (1995). Her-2/neu oncogene characterization in head and neck squamous cell carcinoma. Archives of Otolaryngology - Head and Neck Surgery, 121: 1265-1270.

21. Craven J M, Pavelic ZP, Stambrook PJ, Pavelic L, Gapany M, Kelley DJ , Gapany S \& Gluckman J L (1992). Expression of CerbB-2 gene in human head and neck carcinoma. Anticancer Research, 12: 22732276.

22. Press MF, Pike MC, Hung G, Zhou J Y, Ma Y, George J, Dietz-Band J, James W, Slamon DJ , Batsakis J G \& El-Naggar AK (1994). Amplification and overexpression of HER-2/neu in carcinomas of the salivary gland: correlation with poor progno- 
sis. Cancer Research, 54: 5675-5682.

23. Miyaguchi M, Olofsson J \& Hellquist HB (1990). Expression of epidermal growth factor receptor in laryngeal dysplasia and carcinoma. Acta Oto-Laryngologica, 110: 309-313.

24. Maurizi M, Almadori G, Ferrandina G, Distefano M, Romanini ME, Cadoni G, Benedetti-Panici P, Paludetti G, Scambia $G \&$ Mancuso S (1996). Prognostic significance of epidermal growth factor receptor in laryngeal squamous cell carcinoma. British J ournal of Cancer, 74: 1253-1257.

25. Maurizi M, Scambia $G$, Benedetti-Panici P, Ferrandina G, Almadori G, Paludetti G, De Vicenzo $R$, Distefano $M$, Brinchi $D$, Cadoni G \& Mancuso S (1992). EGF receptor expression in primary laryngeal cancer: correlation with clinico-pathological features and prognostic significance. International J ournal of Cancer, 52: 862866.

26. Berenson J R, Yang J \& Mickel RA (1989). Frequent amplification of the bcl-1 locus in head and neck squamous cell carcinomas. Oncogene, 4: 1111-1116.

27. Muller $D$, Millon $R$, Velten $M$, Bronner $G$, J ung $G$, Engelmann $A$, Flesch $H$, Eber $M$, Methlin G \& Abecassis J (1997). Amplification of 11q13 DNA markers in head and neck squamous cell carcinomas correlation with clinical outcome. European J ournal of Cancer, 33: 2203-2210.

28. Shackleford GM, MacArthur CA, Kwan HC \& Varmus HE (1990). Mouse mammary tumor virus infection accelerates mammary carcinogenesis in Wnt-1 transgenic mice by insertional activation of int-2/Fgf3 and hst-1/Fgf4. Proceedings of the National Academy of Sciences, USA, 90: 740-744.

29. Schuuring $E$, Verhoeven $E$, Litvinov $S$ \& Michalides RJ (1993). The product of the EMS1 gene, amplified and overexpressed in human carcinomas, is homologous to a v-src substract and is located in cell-substratum contact sites. Molecular and Cellular Biology, 13: 2891-2893.

30. Patel AM, Incognito LS, Schechter GL, Wasilenko WJ \& Somers KD (1996). Amplification and expression of ESM-1 (cortactin) in head and neck squamous cell carcinoma cell lines. Oncogene, 12: 3135.

31. Schuuring $E$, Verhoeven $E$, Mooi $W L \&$ Michalides RJ AM (1992). Identification and cloning of two overexpressed genes, U21B31/PRAD1 and EMS1, within the amplified chromosome 11q13 region in human carcinomas. Oncogene, 7: 355361.
32. Hinds PW, Dowdy SF, Eaton EN, Arnold A $\&$ Weinberg RA (1994). Function of a human cyclin gene as an oncogene. Proceedings of the National Academy of Sciences, USA, 91: 709-713.

33. Cordon-Cardo C (1995). Mutation of cell cycle regulators: biological and clinical implications for human neoplasia. American J ournal of Pathology, 147: 545-560.

34. Åkenvall J A, Michalides RJ AM, Minet $A H$, Balm A, Borg A, Dictor MR, J in Y, Loftus B, Meertens F \& Wennerberg J P (1997). Amplification of cyclin D1 in squamous cell carcinoma of the head and neck and the prognostic value of chromosomal abnormalities and cyclin D1 overexpression. Cancer, 79: 380-389.

35. Michalides RJAM, van Veelen NMJ, Kristel PMP, Hart AAM, Loftus BM, Hilgers FJ M \& Balm AJ M (1997). Overexpression of cyclin D1 indicates a poor prognosis in squamous cell carcinoma of the head and neck. Archives of Otolanyngology - Head and Neck Surgery, 123: 497-502.

36. Fracchiola NS, Prunieri G, Pignataro L, Carboni N, Capaccio P, Boletini A, Buffa R $\&$ Neri A (1997). Molecular and immunohistochemical analysis of the bcl-1/cyclin D1 gene in laryngeal squamous cell carcinomas: correlation of protein expression with lymph node metastases and advanced clinical stage. Cancer, 79: 11141121.

37. Ah-See KW, Cooke TG, Pickford IR, Soutar D \& Balmain A (1994). An allelotype of squamous carcinoma of the head and neck using microsatellite markers. Cancer Research, 54: 1617-1621.

38. Maestro R, Gasparotto D, Vukosavljevic $T$, Barzan L, Sulfaro $S \&$ Boiocchi M (1993). Three discrete regions of deletion at $3 p$ in head and neck cancers. Cancer Research, 53: 5775-5779.

39. Califano J, van der Riet P, Clayman G, Westra W, Piantadosi S, Corio R, Lee DJ , Greenberg B, Koch W \& Sidransky D (1996). Genetic progression model for head and neck cancer: implications for field cancerization. Cancer Research, 56: 2488-2492.

40. Nawroz H, Koch W, Anker P, Stroun M \& Sidransky D (1996). Microsatellite alterations in serum DNA of head and neck cancer patients. Nature Medicine, 2: 1035-1037.

41. Serrano M, Hannon GJ \& Beach D (1993). A new regulatory motif in cell cycle control causing specific inhibition of cyclin D/ CDK4. Nature, 366: 704-707.

42. van der Reit $\mathrm{P}$, Nawroz $\mathrm{H}$, Hruban $\mathrm{RH}$,
Corio R, Tokino K, Koch W \& Sidransky D (1994). Frequent loss of chromosome 9p21-22 early in head and neck progression. Cancer Research, 54: 1156-1158.

43. El-Naggar AK, Lai S, Clayman G, Lee J K, Luna MA, Goepfert $H \&$ \& Batsakis J G (1997). Methylation, a major mechanism of p16/CDKN2 gene inactivation in head and neck squamous carcinoma. American J ournal of Pathology, 151: 1767-1774.

44. Reed AL, Califano J, Cairns P, Westra WH, J ones RM, Koch W, Ahrendt S, Eby Y, Sewell D, Nawroz H, Bartek J \& Sidransky D (1996). High frequency of p16 (CDKN2/MTS-1/INK4A) inactivation in head and neck squamous cell carcinoma. Cancer Research, 56: 3630-3633.

45. Gonzáles MV, Pello MF, López-Larrea C, Suárez C, Menéndez MJ \& Coto E (1997). Deletion and methylation of the tumour suppressor gene p16/CDKN2 in primary head and neck squamous cell carcinoma. J ournal of Clinical Pathology, 50: 509-512.

46. Papadimitrakopoulou V, Izzo J, Lippman SM, Lee J S, Fan YH, Clayman G, Ro J Y, Hittelman WN, Lotan R, Hong WK \& Mao $L$ (1997). Frequent inactivation p16 INK4a in oral premalignant lesions. Oncogene, 14: 1799-1803.

47. Greenblatt MS, Bennet WP, Hollstein M $\&$ Harris CC (1994). Mutations in the p53 tumor suppressor gene: Clues to cancer etiology and molecular pathogenesis. Cancer Research, 54: 4855-4878.

48. Hussain SP \& Harris CC (1998). Molecular epidemiology of human cancer: Contribution of mutation spectra studies of tumor suppressor genes. Cancer Research, 58: 4023-4037.

49. Levine AJ (1997). P53, the cellular gatekeeper for growth and division. Cell, 88: 323-331.

50. Cho Y, Gorina S, J effrey PD \& Pavletich NP (1994). Crystal structure of a p53 tumor suppressor-DNA complex: Understanding tumorigenic mutations. Science, 265: 346-355.

51. Bartek J, Bartkova J, Vojtesek B, Stakova Z, Lukas J , Rejthar A, Kovarik J , Midgley CA, Gannon J V \& Lane DP (1991). Aberrant expression of the p53 oncoprotein is a common feature of a wide spectrum of human malignancies. Oncogene, 6: 16991703.

52. Gannon J V, Greaves R, Iggo R \& Lane DP (1990). Activating mutations in p53 produce a common conformational effect. A monoclonal antibody specific for the mutant form. EMBO J ournal, 9: 1595-1602.

53. Burns J E, Baird MC, Clarck LJ , Burns PA, Edigton $\mathrm{K}$, Chapman $\mathrm{C}$, Mitchell $\mathrm{R}$, 
Robertson G, Soutar D \& Parkinson EK (1993). Gene mutation and increased levels of the p53 protein in human squamous cell lines. British J ournal of Cancer, 67: 1774-1784.

54. Ogden GK, Kiddie RA, Lunny DP \& Lane DP (1992). Assessment of p53 protein expression in normal, benign and malignant oral mucosa. J ournal of Pathology, 166: 389-394.

55. Raybaud-Diogène $H$, Tétu $B$, Morency $R$, Fortin A \& M onteil RA (1996). p53 overexpression in head and neck squamous cell carcinoma: review of the literature. Oral Oncology, European J ournal of Cancer, 32B: 143-149.

56. Ahomadegebe J C, Borrois M, Fogel S, Le
Bihan $M L$, Douc-Rasy $S$, Duvillard $P$, Armand J P \& Riou G (1995). High incidence of p53 alterations (mutation, deletion, overexpression) in head and neck primary tumors and metastases; absence of correlation with clinical outcome. Frequent protein overexpression in normal epithelium and early non-invasive lesions. Oncogene, 10: 1217-1227.

57. Boyle J O, Hakim J , Koch W, van der Reit P, Hruban RH, Roa RA, Correo R, Eby YJ , Ruppert J M \& Sidransky D (1993). The incidence of p53 mutations increases with progression of head and neck cancer. Cancer Research, 53: 4477-4480.

58. Nagai MA, Miracca EC, Yamamoto $L$, Moura RP, Simpson AJ, Kowalski LP \&
Brentani RR (1998). TP53 genetic alterations in head and neck carcinomas from Brazil. International J ournal of Cancer, 76: 13-18.

59. Gallo O \& Bianchi S (1995). p53 expression: a potential biomarker for risk of multiple primary malignancies in the upper aerodigestive tract. Oral Oncology, European J ournal of Cancer, 31B: 53-57.

60. Brennan JA, Boyle J O, Koch WM, Goodman SN, Hruban RH, Eby YJ , Couch MJ , Forastiere AA \& Sibransky D (1995). Association between cigarette smoking and mutation of the p53 gene in head and neck squamous carcinomas. New England J ournal of Medicine, 332: 712-717. 